УДК 613.292:638.1+612:68

О. В. Севериновська, К. І. Касимова

Дніпропетровський національний університет

\title{
ВПЛИв БДжОЛИНОГО ПИЛкУ \\ НА ЦЕНТРАЛЬНУ НЕРВОВУ СИСТЕМУ ТВАРИН
}

Досліджено вплив бджолиного пилку на стан центральної нервової системи білих лабораторних щурів. Поведінкові реакції оцінювали у „відкритому полі”, запис біоелектричної активності проводили від лобово-тім'яної кори, дорсального гіпокампа та гіпоталамуса на стандартному електрофізіологічному устаткуванні. Показано, що бджолиний пилок, викликаючи збільшення абсолютних показників складових електричної активності мозку, знижує частку повільних низькочастотних компонентів і підвищує потужність швидких високочастотних. Це проявляється у підвищенні спонтанної рухової активності й розвитку оріснтовно-дослідної стратегії поведінки, що вказує на сприятливий вплив цього препарату на ЦНС.

\section{O. V. Severynovs'ka, K. I. Kasymova \\ Dnipropetrovsk National University \\ INFLUENCE OF BEE POLLEN \\ ON THE CENTRAL NERVOUS SYSTEM OF ANIMALS}

Influence of bee pollen on the state of the central nervous system of white laboratory rats is studied. The behavioural reactions were estimated in ,an opened field”. The bioelectric activity recording was conducted on frontoparietal cortex, dorsal hippocampus and hypothalamus with the standard electro-physiology equipment. It is shown that bee pollen results in the increase of absolute indices of constituents of brain electric activity, in the reduction of the part of slow low-frequency and in the increase of power of fast high-frequency components. It becomes apparent as a rise in the spontaneous motive activity and development of orientative-trying strategy of behaviour, which specifies on favourable influence of this preparation on CNS.

\section{Вступ}

Широке розповсюдження апітерапії в Україні та країнах СНД чітко визначило два напрямки використання продуктів бджільництва в медицині: БАД та сировини для стандартизованих субстанцій лікарських препаратів [2] і природних адаптогенів [10; 11]. Саме тому вивчення, розробка та застосування препаратів прополісу та бджолиного пилку (бджолиного обніжжя) займають головне місце серед продуктів бджільництва.

Відомо, що у свіжозібраному бджолами квітковому пилку міститься до 40 \% білків, 7-10\% ліпідів, усі незамінні амінокислоти й мікроелементи - калій, фтор, кальцій, магній, залізо, які складають $3,8 \%$ [6; 13]. Він багатий на вітаміни: містить $B_{12}, B_{5}, B_{6}, E$, $C, D, P P$, фолієву кислоту [8]. Пилок має активні ферменти та коферменти [7]. Він винятково багатий на каротиноїди, біофлавоноїди та фітостероїди [4]. Фітогормони цього бджолиного продукту мають антибактеріальну дію; фенольні сполуки - протизапальну, капілярозміцнювальну та протипухлинну [12]. Збалансований самою природою склад цього препарату робить його потужним антиоксидантом [9]. У бджолиному пилку (БП) виявлені деценові кислоти, які чинять антиоксидантний стимулювальний вплив на мак-

(C) О. В. Севериновська, К. І. Касимова, 2008 
роорганізми. Пилок стимулює ріст і регенерацію пошкоджених клітин, активізує систему мікросомального окиснення, сприяє зниженню білірубіну в сироватці крові. Пилок відносять до адаптогенів, які підвищують загальну неспецифічну опірність організму до захворювань і радіації $[1 ; 3 ; 14]$. Обніжжя чинить позитивний вплив на процеси обміну в клітині, збільшує іiі здатність до поділу та відновлення. Вважають, що єдиним протипоказанням для вживання бджолиного пилку є розвиток алергічної реакції на нього. Зважаючи на дослідженість цього препарату, залишається питання про його дію на стан центральної нервової системи. Для відповіді на нього були проведені експерименти на лабораторних тваринах.

\section{Матеріал і методи досліджень}

Дослідження проводили на білих статевозрілих лабораторних щурах-самцях вагою 180-220 г. Тварин поділили на контрольну $(n=15)$ та експериментальну $(n=10)$ групи, які отримували разом з їжею один раз на добу БП у дозі 0,07 г/на 100 г ваги тіла протягом 25 діб. Поведінкові реакції експериментальних тварин оцінювали у відкритому полі за методикою [5].

На стереотаксичному приладі під дією наркозу: кетаміну (20 мг/кг) та тіопенталу натрію (50 мг/кг) за атласом [3] уніполярні, сталеві $(d=0,1$ мм) у лаковій ізоляції електроди занурювали у лобно-тім'яну кору, дорсальний гіпокамп, гіпоталамус (anterior hypothalamic area та dorsal hypothalamic area). Після відновлення рухової активності тварин починали запис біоелектричної активності на стандартному електрофізіологічному устаткуванні. Отримані результати обробляли з використанням перетворення Фур'€ (FFT під час усього експерименту). Для нормалізації амплітудно-частотних характеристик використовували вікно Blackman довжиною вибірки досліду. Для найкращого відображення загальних закономірностей спектральної кривої, а також для нівелювання індивідуальних особливостей тварин і чутливості до введених речовин, максимальне значення спектральної потужності (визначене у мк $\mathrm{B}^{2}$ ) приймали за $100 \%$ і будували спектри, застосовуючи пакет програм Matlab 7.0. Також розраховували питому вагу кожної ритмічної складової, приймаючи за 100 \% загальну потужність біоелектричної активності за 10 с. Для побудови графічних зображень використовували Origin 6.0, Оцінку достовірності змін проводили за допомогою $t$-критерію Стьюдента.

\section{Результати та їх обговорення}

У тварин, які протягом 25 діб як додаток до раціону отримували бджолиний пилок, на першу експериментальну добу тестування у “відкритому полі" спостерігали підвищення загальної рухової активності, причому як за рахунок горизонтального компонента, так і вертикального (табл. 1). Також у цих щурів відмічали тенденцію до збільшення кількості актів грумінгів і часу завмирання на одному місці, що свідчить про підвищену емоційність тварин і може пояснюватись настороженою поведінкою тварин у новому відкритому просторі. Отже, на початку тестування дослідні тварини характеризувалися підвищеною локомоторною та орієнтовно-дослідницькою активністю. Про останню свідчить збільшення ніркового рефлексу.

Наступної доби спостерігалося подальше підвищення загальної рухової активності тварин, при цьому деякі компоненти підвищилися більше ніж удвічі. Горизонтальна рухова активність другої групи тварин зросла у 1,9, а вертикальна - у 3,0 раза відносно контролю. Суттєво зменшився час завмирання тварин на одному місці. Отримані дані свідчать не тільки про підвищення локомоторної складової поведінки, а і про високий рівень розвитку збудження у дослідних тварин. Показник пошукової активності (зази- 
рання у нірки) зменшився порівняно з першою спробою, але все-таки був на $68,8 \%$ вищим за контроль. Тривалі акти грумінгу не спостерігались, кількість і частота відвідування квадратів внутрішнього поля зросли, що говорить про формування адаптивної реакції до відкритого простору.

На третю добу поведінка тварин, що вживали бджолиний пилок, характеризувалася тенденцією до зміни тактики, яка виражалася у зниженні горизонтального компонента, ніркового рефлексу, часу завмирання на одному місці, кількості актів грумінгів, які стають тривалішими. Вертикальний компонент на даному етапі спостереження перевищував контрольні значення. Таким чином, у цей період у експериментальних щурів спостерігалося пригнічення більшості форм активності.

Поведінковий патерн щурів-самців у „відкритому полі”

Табличя 1

\begin{tabular}{|c|c|c|c|c|}
\hline \multirow{2}{*}{ Поведінкові реакції щурів } & \multicolumn{4}{|c|}{ Час тестування, спроба } \\
\hline & 1 & 2 & 3 & 4 \\
\hline \multirow[b]{2}{*}{ Кількість зовнішніх квадратів } & $\underline{22,10 \pm 1,52}$ & $\underline{15,20 \pm 1,13}$ & $\underline{24,40 \pm 2,25}$ & $\underline{21,40 \pm 1,86}$ \\
\hline & $30,57 \pm 3,50^{*}$ & $27,14 \pm 5,02 *$ & $19,43 \pm 3,13$ & $23,57 \pm 2,98$ \\
\hline \multirow{2}{*}{ Кількість внутрішніх квадратів } & $1,50 \pm 0,34$ & $\underline{0,90 \pm 0,31}$ & $4,40 \pm 0,77$ & $2,60 \pm 0,71$ \\
\hline & $2,14 \pm 0,40$ & $2,71 \pm 0,42 * *$ & $3,14 \pm 0,67$ & $3,86 \pm 0,59$ \\
\hline \multirow{2}{*}{ Горизонтальна рухова активність } & $23,60 \pm 1,81$ & $16,10 \pm 1,32$ & $28,80 \pm 2,55$ & $24,00 \pm 2,42$ \\
\hline & $32,71 \pm 3,71 *$ & $29,86 \pm 5,13^{*}$ & $22,51 \pm 3,57$ & $27,43 \pm 3,42$ \\
\hline \multirow{2}{*}{$\begin{array}{l}\text { Частота відвідування } \\
\text { внутрішнього поля }\end{array}$} & $\underline{1,00 \pm 0,14}$ & $\underline{0,80 \pm 0,24}$ & $\underline{2,10 \pm 0,34}$ & $\underline{1,50 \pm 0,40}$ \\
\hline & $\overline{1,00 \pm 0,22}$ & $\overline{1,14 \pm 0,26}$ & $\overline{1,29 \pm 0,28}$ & $\overline{1,43 \pm 0,29}$ \\
\hline \multirow{2}{*}{ Кількість стійок } & $5,20 \pm 0,94$ & $2,60 \pm 0,49$ & $8,10 \pm 1,31$ & $\underline{3,90 \pm 0,83}$ \\
\hline & $18,43 \pm 1,90 * * *$ & $10,71 \pm 1,63^{* * *}$ & $10,29 \pm 0,29$ & $11,71 \pm 1,43^{* * *}$ \\
\hline \multirow{2}{*}{ Кількість актів грумінгу } & $\underline{1,20 \pm 0,38}$ & $\underline{0,80 \pm 0,29}$ & $\underline{1,50 \pm 0,54}$ & $1,70 \pm 0,44$ \\
\hline & $2,29 \pm 0,36^{*}$ & $2,71 \pm 0,52 * *$ & $\overline{1,29 \pm 0,36}$ & $\overline{1,86 \pm 0,26}$ \\
\hline \multirow[b]{2}{*}{ Вертикальна рухова активність } & $6,40 \pm 1,16$ & $\underline{3,40 \pm 0,65}$ & $9,60 \pm 1,52$ & $5,60 \pm 1,00$ \\
\hline & $20,71 \pm 2,20 * * *$ & $13,43 \pm 1,61^{* * *}$ & $11,51 \pm 3,46$ & $13,57 \pm 1,49 * * *$ \\
\hline \multirow{2}{*}{ Загальна рухова активність } & $\underline{30,00 \pm 2,58}$ & $\underline{19,50 \pm 1,55}$ & $\underline{38,40 \pm 3,04}$ & $\underline{29,60 \pm 2,82}$ \\
\hline & $53,43 \pm 5,57 * * *$ & $43,29 \pm 6,01 * * *$ & $34,14 \pm 6,78$ & $41,00 \pm 4,26^{*}$ \\
\hline \multirow{2}{*}{ Тривалість актів грумінгу, с } & $\underline{5,00 \pm 2,98}$ & $\underline{4,00 \pm 3,05}$ & $\underline{3,00 \pm 2,13}$ & $\underline{7,00 \pm 3,95}$ \\
\hline & - & - & $4,29 \pm 2,02$ & - \\
\hline \multirow{2}{*}{ Нірковий рефлекс } & $\underline{2,90 \pm 0,45}$ & $2,20 \pm 0,64$ & $8,30 \pm 1,00$ & $4,00 \pm 0,80$ \\
\hline & $5,43 \pm 0,89 *$ & $3,71 \pm 0,35^{*}$ & $5,14 \pm 0,70^{*}$ & $\overline{3,86 \pm 0,45}$ \\
\hline \multirow{2}{*}{ Час завмирання на одному місці, с } & $8,50 \pm 5,58$ & $\underline{55,00 \pm 12,40}$ & $\underline{25,00 \pm 6,79}$ & $\underline{37,00 \pm 7,23}$ \\
\hline & $\overline{11,43 \pm 1,80}$ & $2,14 \pm 2,14 * * *$ & $\overline{15,71 \pm 2,29}$ & $\overline{28,57 \pm 7,04}$ \\
\hline
\end{tabular}

Примітка: у чисельнику - значення показників контрольних тварин, у знаменнику - значення показників тварин, що вживали бджолиний пилок; достовірні відміни від контролю: * $-p<0,05$, $* *-p<0,01, * * *-p<0,001$.

Завершальна частина тестування у відкритому полі характеризувалася збільшенням загальної рухової активності на 38,5 \% за рахунок достовірного росту вертикального компонента (удвічі) та кількості пересічених квадратів внутрішнього поля на $48,4 \%$, а також зменшенням часу завмирання та відсутністю тривалих актів грумінгу. Наприкінці тестування у тварин, які отримували бджолиний пилок (бджолине обніжжя), орієнтовно-дослідницька активність у цілому була наближеною до контролю.

Слід зазначити, що після початкового періоду (перша та друга спроби) локомоторної горизонтальної активності щурів-самців на третю спробу відбулося природне зниження їх рухової (використаної для накопичення первинної інформації) та пошукової активності, необхідної для цілеспрямованого вивчення навколишнього середовища. Четверта характеризувалася вторинним посиленням спонтанної рухової активності, яка, 
скоріше за все, пов'язана з реалізацією стратегії пошуку у знайомому середовищі. У цілому, поведінку тварин, що вживали природний препарат як добавку до їжі, за більшістю показників орієнтовно-дослідницької та локомоторної активності можна назвати близькою до контролю. Виявлене вірогідне підвищення вертикального компонента рухової активності (рис. 1), в основному за рахунок стійок, що також вплинуло на підвищення загальної рухової активності та зниження часу завмирання тварин на одному місці. Також відмічали підвищення дослідження центральної площі відкритого простору. Отримані дані свідчать про те, що під впливом бджолиного пилку відбувається підвищення рухової активності тварин, що, скоріше за все, пов'язано із властивостями адаптогену та його можливістю впливати на процеси обміну в організмі.

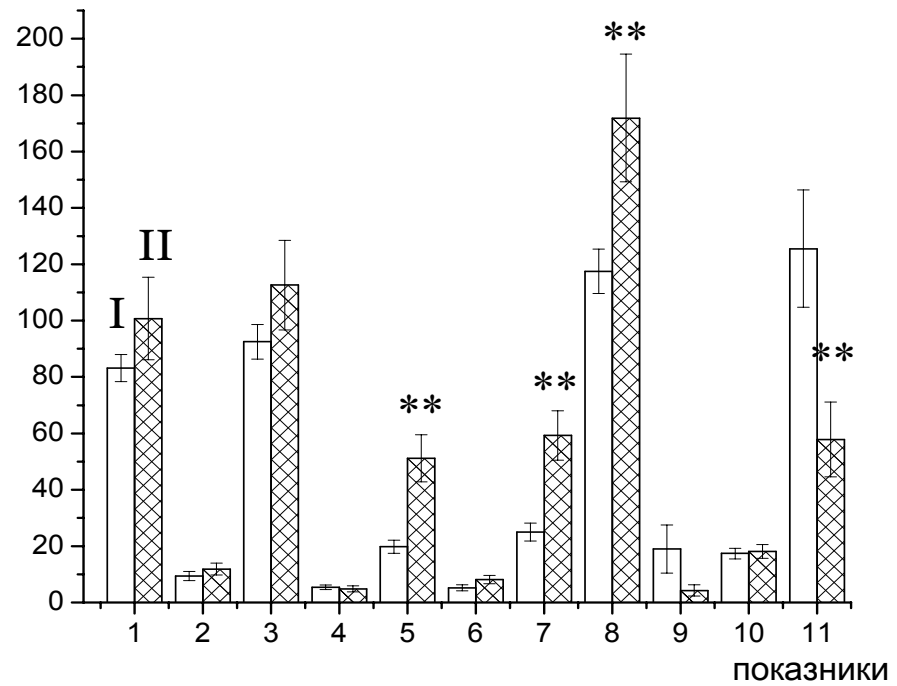

Рис. 1. Динаміка психоемоційних патернів щурів у „відкритому полі”:

$I$ - контроль, $I I$ - експеримент; за віссю абсцис - показники поведінкових реакцій тварин: відвідування зовнішніх квадратів (1), відвідування внутрішніх квадратів (2), загальна горизонтальна активність (3), частота відвідування внутрішніх квадратів (4), кількість підйомів на задні лапи (5), кількість актів грумінгу (6), загальна вертикальна активність (7), загальна рухова активність (8), тривалість актів грумінгу, у с (9); відвіданих нірок (10), час завмирання тварини, у с (11); за віссю ординат - середнє значення показників у відповідних одиницях; достовірні відміни від контролю: ${ }^{*}-p<0,05, * *-p<0,01$.

Для того, щоб досконаліше розібратись у фізіологічних механізмах впливу бджолиного пилку на ЦНС, проводили оцінку пї функціонального стану за допомогою реєстрації та аналізу електричної активності морфологічно та функціонально різних відділів головного мозку щурів. Встановлено, що при використанні бджолиного обніжжя протягом місяця показники відносної спектральної потужності кожної ритмічної складової (за середніми значеннями) в усіх вивчених відділах мозку дослідних тварин вірогідно збільшились у всіх діапазонах (рис. 2). Це свідчить про дезорганізацію основного ритму та активацію головного мозку, що, можливо, пов’язано з інтенсифікацією процесів обміну під впливом цього природного адаптогену. Слід відзначити, що тривале використання адаптогену (протягом двох місяців) практично не змінювало загальної картини біоелектричної активності, а показники відносної спектральної потужності були подібними до попередніх.

Цікавим виявилося відношення спектральної потужності низькочастотних компонентів (дельта- і тета-) до високочастотних (альфа- та бета-) електричної активності: у неокортексі - 1,71:1 (тоді як у контролі - 3,05:1), у гіпокампі - 2,05:1 (у контролі - 
1,97:1), у передній зоні гіпоталамуса - 1,71:1 (у контролі - 2,16:1), у задній зоні гіпоталамуса - 1,66:1 (у контролі - 2,04:1). У корі головного мозку тварин, які протягом місяця вживали бджолиний пилок, питома вага всіх складових (рис. 3) коливалася в області контрольних значень, проте при тривалішому вживанні пилку спостерігали вірогідне збільшення кількості швидких хвиль.
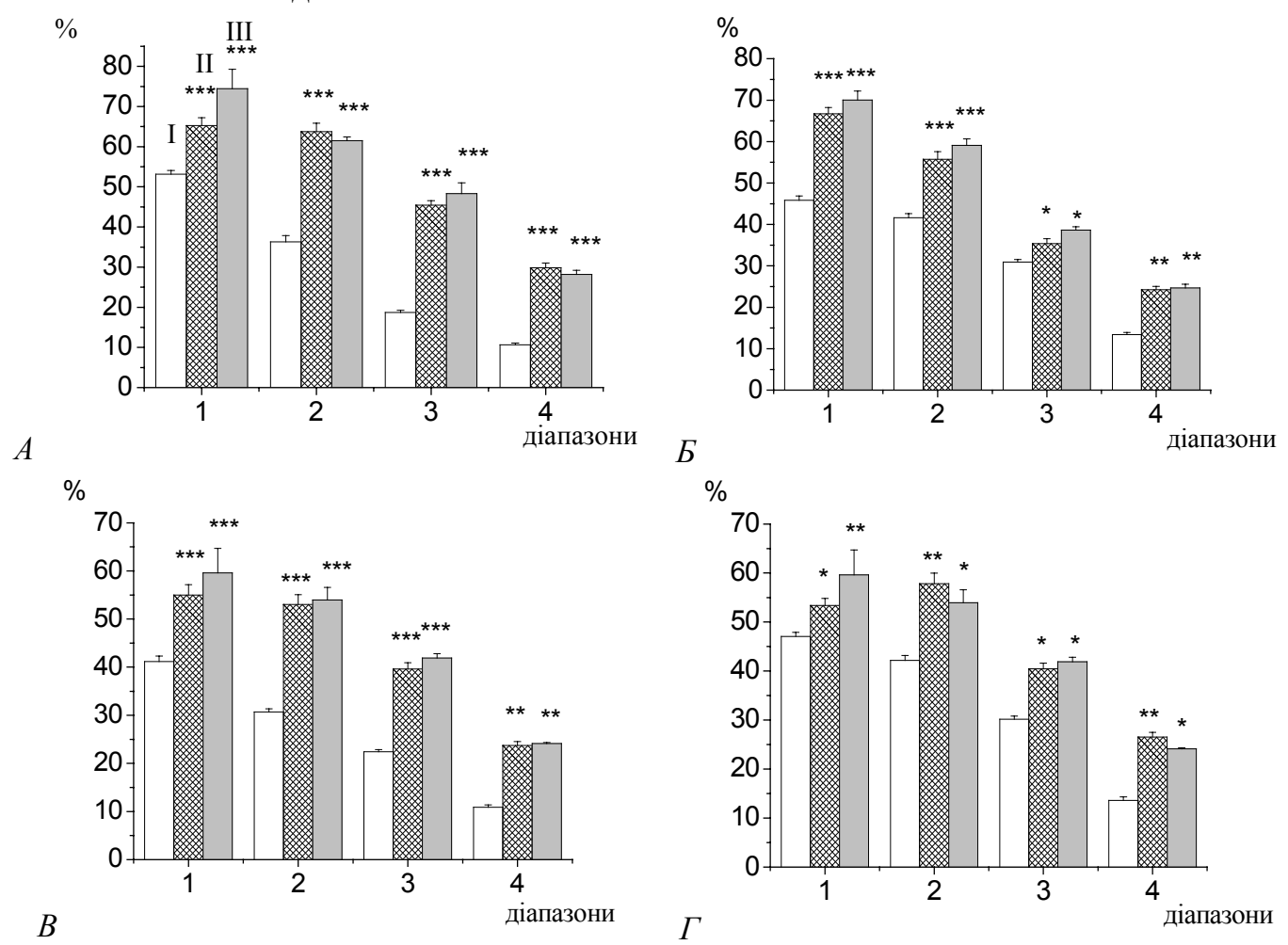

Рис. 2. Середні значення відносної спектральної потужності ритмічних складових біоелектричної активності: неокортекса $(A)$, дорсального гіпокампа $($ b), передньої ділянки гіпоталамуса $(B)$, задньої ділянки гіпоталамуса $(\Gamma)$ щурів I групи - контрольної $(n=25)$, II групи - тих, що вживали бджолиний пилок протягом місяця $(n=25)$, ІІІ групи - тих, що вживали бджолиний пилок протягом двох місяців $(n=25)$; за віссю ординат - спектральна потужність $\left(\mathrm{мB}^{2}\right)$, максимальне значення якої прийняте за $100 \%$; за віссю абсцис - 1 - $\delta$-діапазон; 2 - $\theta$-діапазон, 3 - $\alpha$-діапазон, 4 - $\beta$-діапазон; достовірні відміни від контролю, при * $-p<0,05, * *-p<0,01,{ }^{* * *}-p<0,001$.

У гіпоталамусі, навпаки, відмічали збільшення кількості дельта- і тета-складових при місячному курсі вживання цього адаптогену. Подібний характер змін при вживанні бджолиного пилку протягом місяця спостерігали у відділах гіпоталамуса: збільшення індексу дельта- і тета-складових і зменшення кількості альфа- і бета-хвиль. Проте триваліше споживання цього препарату призводило до наближення кількісних показників спектральної потужності досліджених ритмів до контрольних значень.

\section{Висновки}

Вживання бджолиного пилку, викликаючи збільшення абсолютних показників складових електричної активності мозку, знижує частку повільних низькочастотних компонентів та підвищує потужність швидких високочастотних. 3 одного боку, це відбивається на підвищенні спонтанної рухової активності та розвитку орієнтовно-дослідної стратегії поведінки, що вказує на сприятливий вплив цього бджолиного препарату на центральну нервову систему. 


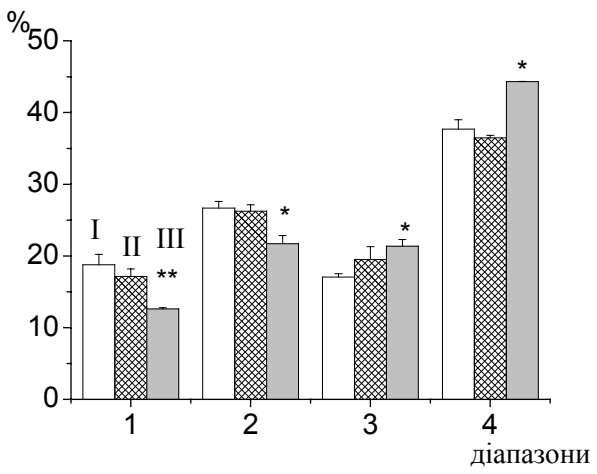

$A$

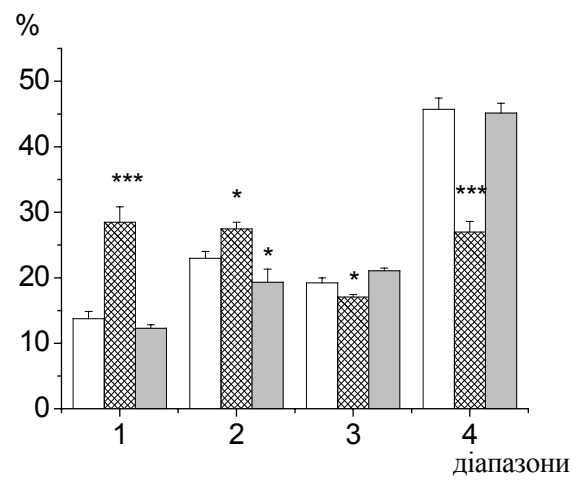

$B$

Рис. 3. Питома вага ритмічних складових біоелектричної активності:

неокортекса $(A)$, дорсального гіпокампа $(Б)$, передньої ділянки гіпоталамуса $(B)$, задньої ділянки гіпоталамуса $(\Gamma)$ щурів I групи - контрольної $(n=25)$, II групи - тих, що вживали бджолиний пилок протягом місяця $(n=25)$, III групи - тих, що вживали бджолиний пилок протягом двох місяців

$(n=25)$; за віссю ординат - питома вага ритмічних складових біоелектричної активності, \%; за віссю абсцис: 1 - $\delta$-діапазон; 2 - $\theta$-діапазон, 3 - $\alpha$-діапазон, 4 - $\beta$-діапазон; достовірні відміни від контролю, при * $-p<0,05, * *-p<0,01, * * *-p<0,001$.

3 іншого - може бути свідченням переходу організму під дією бджолиного пилку на новий функціональний рівень гомеостазу, про що свідчать попередні наші дослідження [15]. Вивчений адаптоген при досить тривалому вживанні, призводячи до якісних змін енергії ритмів, не спричиняє кількісних змін складових біоелектричної активності, тоді як вживання цієї біодобавки впродовж місяця викликає якісні та кількісні зміни складових біоелектричної активності.

\section{Бібліографічні посилання}

1. Ананьева Т. В. Эффекты $\beta$-каротинового масла и пчелиной обножки при радиационнохимическом воздействии на ионный транспорт в срезах мозга крыс / Т. В. Ананьева, А. И. Дворецкий // Радиац. биология. Радиоэкология. - 1999. - Т. 39, № 2-3. - С. 341-344.

2. Батрак А. Апитерапия: взгляд в зеркало // Провизор. - 2002. - Вып. 22. - С. 12.

3. Бевзо В. В. Стан антиоксидантної системи організму мишей при дії малих доз радіації та іï корекція екстрактом бджолиного пилку: Автореф. дис. ... канд. біол. наук: 03.00 .04 / Чернівецький держ. ун-т ім. Ю. Федьковича. - Чернівці, 1997. 
4. Бородина Т. М. Понятие о БАД, их классификация и возможности применения. Метод. разработка. - Пятигорск, 1999. - С. 10-23.

5. Буреш Я. Методики и основные эксперименты по изучению мозга и поведения / Я. Буреш, О. Бурешова, Д. П. Хьюстон. - М.: Высшая школа, 1991. - 399 с.

6. Дорошенко В. Е. Азы пчеловодства и применение пчелиных лекарств / В. Е. Дорошенко, И. Н. Воронцов. - К.: Знание, 1993. - С. 43-45.

7. Машенков О. Н. Живительная сила «пчелиного хлеба» // Пчеловодство. - 2003. - № 1. - С. $42-44$.

8. Применение пыльцы при различных анемиях / В. Н. Бекетов, Ю. О. Берман, В. А. Кондурцев, Э. Ш. Нижарадзе // Пчеловодство. - 2003. - № 2. - С. 45-48.

9. Роль биологически активных добавок в обеспечении защиты от радиационного поражения / А. И. Дворецкий, Е. В. Севериновская, Ю. Б. Кудряшов, Е. Г. Егорова // Роль біологічно активних добавок у забезпеченні здоров’я населення. Матер. науково-практ. конф. - 2001. - С. 29-30.

10. Севериновська О. В. Застосування природного адаптогену для корекції зсувів про-/антиоксидантного балансу організму / О. В. Севериновська, О. Ю. Зайченко, М. О. Григорова // Клінічна та експериментальна патологія. - 2006. - Т. 5, № 1. - С. 114-117.

11. Теоретичні основи природного захисту при радіаційно-хімічному навантаженні на організм / А. І. Дворецький, О. В. Севериновська, О. Ю. Зайченко та ін. // Матер. V Междунар. симпоз. «Безопасность жизнедеятельности в XXI веке". - 2005. - С. 37.

12. Футковская Ж. А. Поиск новыХ средств для повышения радиорезистентности облученного организма / Ж. А. Футковская, Т. С. Морозкина, Е. Ф. Конопля // Тр. Всерос. конф. «Проблемы противолучевой защиты». - М., 1998. - С. 7.

13. Шкендеров С. Пчелиные продукты / С. Шкендеров, И. Иванов. - София: Земиздат, 1985. C. 201-223.

14. Эффекты низкоинтенсивного облучения на систему антиоксидантной защиты и оценка эффективности природного адаптогена в разных отделах головного мозга крыс / Е. В. Севериновская, М. А. Григорова, Е. Ю. Зайченко, А. И. Дворецкий // Биологические эффекты малых доз ионизирующей радиации и радиоактивное загрязнение среды. - Сыктывкар, 2006. - С. 124-126.

15. Modification effects of natural adaptogen under radiation-chemical alteration of active ion transport in neuronal membranes / E. V. Severinovskaya, A. I. Dvoretsky, E. G. Egorovaet al. // Proc. of the 30th Annual Meeting of the European Society for Radiation Biology. - Warszawa, Poland, 2000. - P. 94.

16. Paxions G. The Rat Brain in Stereotaxis Coordinates / G. Paxions, C. Watsons. - San Diego, CA: Academic Press, 1986. - 135 c.

Надійшла до редколегії 10.02.2007 